\title{
Oregano essential oil as food additive for piglets: antimicrobial and antioxidant potential
}

\author{
João Dionísio Henn ${ }^{1}$, Teresinha Marisa Bertol ${ }^{2}$, Neusa Fernandes de Moura ${ }^{1}$, Arlei \\ Coldebella ${ }^{2}$, Paulo Antônio Rabenschlag de Brum², Maurício Casagrande ${ }^{1}$
}

\author{
1 Universidade Comunitária Regional de Chapecó - UNOCHAPECÓ. Centro de Ciências Agro-Ambientais e de Alimentos - CCAA. \\ Av. Sen. Atílio Fontana, 591-E, Bairro Efapi - CEP: 89809-000. Caixa Postal 747 - Chapecó, SC.
}

2 Embrapa Suínos e Aves. BR 153, km 110, Distrito de Tamanduá, Caixa Postal 21, CEP: 897000-000.

\begin{abstract}
This study aimed to investigate the effect of dietary supplementation of oregano essential oil on the performance and on the occurrence of diarrhea in weanling pigs, as well as its antioxidant and antimicrobial activity evaluated in vitro. It was compared four treatments (diets): negative control; positive control, $0.5 \% \mathrm{ZnO}$ (preventive diarrhea) + $0.05 \%$ zinc acitracin (growth promoter); or $0.003 \%$ of essential oil of oregano, combined or not with preventive of diarrhea. Weight gain, feed intake and feed conversion were evaluated from 27 (weaning) to 62 days of age of the animals, and the occurrence of diarrhea was evaluated on the first 14 days of the experiment. The positive control diet and the oregano oil + zinc oxide diet were the ones that provided the best zootechnical performance. The number of piglets with diarrhea, as well as the duration of diarrhea, were lower in animals fed positive control and oregano oil + zinc oxide diets. Oregano oil had in vitro bacteriostatic action on all the tested microorganisms and bactericidal action against four bacteria. The in vitro antioxidant activity of oregano oil was $98.88 \%$ through linoleic acid/ $\beta$-carotene system methodology, and $174.17 \mathrm{mg} / \mathrm{mL}$ by the DPPH method, expressed as $\mathrm{CE}_{50}$. Oregano oil shows potent antioxidant effect and a strong antimicrobial activity, however, it does not improve the zootechnical performance neither it is efficient in preventing diarrhea in weanling pigs.
\end{abstract}

Key Words: growth promoter, natural additives, nutrition, Origanun vulgare, swine

\section{Óleo essencial de orégano como aditivo alimentar para leitões: potencial antimicrobiano e antioxidante}

\begin{abstract}
RESUMO - Com este estudo objetivou-se verificar o efeito da suplementação dietética do óleo essencial de orégano no desempenho e na ocorrência de diarréia em leitões recém-desmamados, bem como suas atividades antimicrobiana e antioxidante avaliadas in vitro. Foram comparados quatro tratamentos (dietas): controle negativo; controle positivo, 0,5\% ZnO (preventivo diarréia) + 0,05\% bacitracina de zinco (promotor de crescimento); ou com 0,003\% de óleo essencial de orégano, combinado ou não ao preventivo da diarreia. O ganho de peso, consumo de ração e conversão alimentar foram avaliados dos 27 (desmame) aos 62 dias de idade dos animais, e a ocorrência de diarréia foi avaliada nos primeiros 14 dias de experimento. A dieta controle positivo e aquela com óleo de orégano + óxido de zinco foram as que proporcionaram o melhor desempenho zootécnico. O número de leitões que apresentaram diarréia, assim como a duração da diarréia, foi menor nos animais que receberam as dietas controle positivo e óleo + óxido de zinco. O óleo de orégano teve ação bacteriostática in vitro sobre todos os microorganismos testados e ação bactericida contra quatro bactérias. A atividade antioxidante in vitro do óleo de orégano foi de 98,88\% pela metodologia do sistema $\beta$-caroteno/ácido linoléico, e de $174,17 \mathrm{mg} / \mathrm{mL}$ pelo método de $\mathrm{DPPH}$, expresso em $\mathrm{CE}_{50}$. O óleo de orégano apresenta potente efeito antioxidante e forte atividade antimicrobiana, mas não melhora o desempenho zootécnico nem é eficaz na prevenção de diarréia em leitões recém-desmamados.
\end{abstract}

Palavras-chave: aditivos naturais, nutrição, Origanun vulgare, promotor de crescimento, suínos

\section{Introduction}

In nutritional programs for swine, antibiotic and anti-microbial additives that act as growth promoters have been used in sub-therapeutic and constant doses ever since the 1950s. In post -weaning, these additives promote an average increase of $16.4 \%$ in weight gain and 6.9\% in feed efficiency (Cromwell, 1991). However, despite of the evidenced ability on improving the growth performance, the use of these products in animal nutrition has been restricted by virtue of legislation in some countries. 
The reduction in the use of antibiotics as growth promoters in animal production has led to the investigation of variants in which substances found in vegetables are presented as alternative options to the use of these products. The possible mechanisms of action of herbal extracts in animal organisms are related to alterations in the intestinal microbiota, increase in digestibility, absorbance of nutrients, and antimicrobial and immunomodulator effects (Mellor, 2000). Anthelmintic, antibiotic and antioxidant activities have been proven in some active compounds present in herbal extracts (Kamel, 2000; Hernández et al., 2004). The fast metabolization and short half-life of active compounds lead to the belief that there is a minimum risk of accumulation in the tissues Kohlert et al. (2000).

More than 30 chemical antibacterial compounds have been found in oregano (Origanum vulgare), but only three or four out of them act isolatedly in the concentration found in this vegetable (Kamel, 2000). Phenolic carvacrol compound is an example and according to Smink (2003), it acts in the cellular wall of the bacteria promoting the rupture of the outer membrane, altering its permeability in relation to cations, causing their death.

The main effects studied in in vitro experiments include the antimicrobial and antioxidant effects of herbal extracts (Ader et al., 2000; Lambert et al., 2001; Kalemba \& Kunicka, 2003). However, although in vitro actions have been proved to exist, the results of experimental research on the comparison between the addition of synthetic antimicrobials and vegetable extracts in swine diets are scarce and with varying results (Oetting et al., 2006; Hauptli et al., 2007). This study was accomplished aiming at evaluating the effect of oregano essential oil in the diets of weaned piglets in relation to their growth performance, incidence of diarrhea, blood parameters, as well as antioxidant and antimicrobial activities determined in vitro.

\section{Material and Methods}

The antioxidant and antimicrobial activities were determined in vitro in the oil extracted from in natura leaves of Origanum vulgare which were submitted to the steam drag distillation (4 hours) using the modified 'Clevenger'. The oil was stored in a refrigerator in amber-colored glass jars with silicone tops. For the antimicrobial activity evaluation, the microorganisms used were Escherichia coli (ATCC8739), Salmonella typhimurium (ATCC14028), Shigella dysenteriae (NCTC7919), Clostridium perfringens (NCTC8798), Staphylococcus aureus (ATCC29213) and
Bacillus cereus (ATCC14579), which were acquired lyophilized from the Coleção de Culturas do Instituto Adolfo Lutz in São Paulo.

The evaluation of antibacterial activity was done through the minimal inhibitory concentration and minimal lethal concentration of oregano essential oil, through the microdillution in soybean casein broth according to the AOAC methodology (1995). The initial mass used for the microbiological analysis was $20 \mathrm{mg}$. The oil was diluted in $280 \mu \mathrm{L}$ methanol, stock solution, from which $200 \mu \mathrm{L}$ was transferred to tubes containing $1,300 \mu \mathrm{L}$ soy casein broth (work solution). The inoculum was prepared from $100 \mu \mathrm{L}$ bacterial solution in a concentration of $1.5 \times 10^{8} \mathrm{ufc} / \mathrm{mL}$ for tubes containing $5 \mathrm{~mL}$ the soy casein broth. It was transferred $100 \mu \mathrm{L}$ pure soybean casein broth to all the wells in the last row (negative control) and after that $100 \mu \mathrm{L}$ culture medium with the inoculum was added into all the wells. The work solution from the first well was transferred in triplicates and the microdillutions were made at the following concentrations $10 ; 5 ; 2.5 ; 1.25 ; 0.625 ; 0.312 ; 0.156$ and $0.078 \mathrm{mg} / \mathrm{mL}$. The covered dishes were incubated at $35^{\circ} \mathrm{C}$ for 24 hours and read with the aid of developer trifenil tetrazolium chloride solution. For positive control, chloramphenicol was used. After the determination of the minimal inhibitory concentration, $10 \mu \mathrm{L}$ from the well with no bacterial growth were transferred to Petri dishes containing sterile nutrient agar. The plaques were inverted and incubated in a heater at $35^{\circ} \mathrm{C}$ for 24 hours. At this point, a reading was done in which the minimum inhibitory concentration of oil corresponded to the lowest concentration without any microbial growth in the platelets.

For the in vitro antioxidant activity of the oregano essential oil, two methodologies were used: $\beta$-carotene Linoleic acid and DPPH (1,1-diphenyl-2-picryl hydrazyl) system. Concerning to the first one, the antioxidant activity was determined according to the methodology described by Marco (1968), with modifications. For the preparation of the $\beta$-carotene linoleic acid emulsion, $1 \mathrm{mg} \beta$-carotene was added to $10 \mathrm{~mL}$ of chloroform. After homogenization, $1 \mathrm{~mL}$ this solution was transferred to a round-bottom flask containing $22 \mu \mathrm{L}$ linoleic acid and $90 \mu \mathrm{L}$ Tween 40 . The chloroform mixture was evaporated at $50^{\circ} \mathrm{C}$ for 10 minutes, $50 \mathrm{~mL}$ aerated distilled water was added (saturated in oxygen for 30 minutes) and shaken into an emulsion. From the $\beta$-carotene linoleic acid emulsion, $5 \mathrm{~mL}$ were taken for the blank reading and $10 \mathrm{~mL}$ to be added to $10 \mu \mathrm{L}$ of oregano oil diluted in $10 \mathrm{~mL}$ methanol. They were heated in a water bath at $50^{\circ} \mathrm{C}$ for 15 minutes and then cooled for 10 minutes. The reading was carried out in spectrophotometer with a wave length of $470 \mathrm{~nm}$ in 15- minute intervals for 2 hours. The 
activity was determined in percentage (\%) of antioxidant activity according to the equation: \% antioxidant activity $=100-$ (initial absorbance - final absorbance $)$ sample $\times 100 /$ (initial absorbance - final absorbance) blank.

The method used for the determining antioxidant activity through radical DPPH (1,1-diphenyl-2-picryl hydrazyl) was the Brand-Williams et al. (1995) with modifications from Mensor et al. (2001). Initially, a solution of $0.004 \%$ DPPH in methyl alcohol was prepared. To prepare the sample, $40 \mathrm{mg}$ oregano oil was diluted in $10 \mathrm{~mL}$ alcohol at $97 \%$. Methyl alcohol at $97 \%$ and the solutions of the samples at different concentrations (5, 10, 25, 50, 125 e $250 \mu \mathrm{L} / \mathrm{mL}$ ) were added to the tubes containing $1 \mathrm{~mL}$ DPPH. They were homogenized and left to rest protected from the light for 30 minutes. A control was prepared with $2.5 \mathrm{~mL}$ methanol and $1 \mathrm{~mL}$ DPPH solution. After 30 minutes of reaction, the absorbance was read in $517 \mathrm{~nm}$ in a spectrophotometer and converted into percentage of antioxidant activity using the following equation: $\%$ antioxidant activity $=100-$ (absorbance of the sample) x 100 (control absorbance). The $\mathrm{CE}_{50}$ or the minimum concentration with $50 \%$ antioxidant activity was calculated using linear regression.

The growth performance experiment was conducted at the experimental swine nursery at the Centro Nacional de Pesquisa de Suínos e Aves - Embrapa, from $19^{\text {th }}$ July to $9^{\text {th }}$ September 2007. Four diets were evaluated: negative control - basal diet, without antibiotics growth promoters and without oregano oil; positive control - basal diet with the addition of $0.5 \%$ zinc oxide (diarrhea preventive) and $0.05 \%$ zinc Bacitracin (growth promoter); oregano essential oil - basal diet with the inclusion of $0.003 \%$ oregano essential oil; oregano essential oil + zinc oxide - basal diet with the inclusion of $0.003 \%$ oregano essential oil and $0.5 \%$ zinc oxide.

The pre-initial diets (Table 1) were supplied for 14 days from the day of the weaning. In the next phase, the initial diet was given for all the pigs, from the $15^{\text {th }}$ to the $35^{\text {th }}$ day post-weaning. The experimental diets were formulated considering the nutritional requirements of piglets in the nursery phase and according to the nutritional composition and availability of the nutrients in the ingredients used (NRC, 1998; Rostagno et al., 2005). The kaolin (inert) of the basal diet was substituted by the additives, in accordance to the treatments. The mineral and vitamin supplements were devoid of any kind of growth promoter or antibiotic. The animals were fed ad libitum during the experimental period (35 days).

One hundred and twenty piglets with an average age of $27.3 \pm 0.44$ days and an average initial weight of
$9.25 \pm 0.12 \mathrm{~kg}$ were distributed in five animals of the same sex per pen, totaling three pens of male and three pens of female per diet. The experiment was conducted in blocks over time, with a difference of 14 days from one group to another. In the first group, 80 piglets were used, half castrated males and half females, distributed in the four diets. In the second group, 40 animals were used, distributed in the same manner as the first group. In each group, the piglets were distributed in blocks according to sex and initial weight without considering the genetic ascendance. Evaluations were carried out in relation to growth performance (body weight, feed consumption, weight gain and feed conversion ratio), blood parameters and also to evaluate the occurrence of diarrhea on the first 14 days after weaning, using the following score:

Table 1 - Nutritional composition and ingredients of the basal diets

\begin{tabular}{|c|c|c|}
\hline Ingredients \% & Pre-initial & Initial \\
\hline Ground corn & 10.87 & 39.29 \\
\hline Pregelatinized corn & 20.00 & - \\
\hline Wheat flour & 10.00 & 10.00 \\
\hline Whey powder & 5.00 & 3.00 \\
\hline Lactose & 10.71 & - \\
\hline Soybean oil & 3.29 & 4.06 \\
\hline Sugar & 3.00 & - \\
\hline Soybean meal & 15.00 & 39.72 \\
\hline Texturized soybean protein & 16.87 & - \\
\hline L-lysine & 0.44 & 0.10 \\
\hline DL-methionine & 0.32 & 0.06 \\
\hline L-threonine & 0.30 & 0.03 \\
\hline L-tryptophan & 0.04 & - \\
\hline Dicalcium phosphate & 1.79 & 1.46 \\
\hline Limestone & 0.76 & 0.87 \\
\hline Salt & 0.35 & 0.35 \\
\hline Vitamin premix $^{1}$ & 0.20 & 0.15 \\
\hline Mineral premix ${ }^{2}$ & 0.15 & 0.10 \\
\hline Choline chloride (60\%) & 0.14 & 0.05 \\
\hline Kaolin & 0.55 & 0.55 \\
\hline Antioxidant (BHT) & 0.01 & 0.01 \\
\hline Mycotoxins adsorbent & 0.20 & 0.20 \\
\hline \multicolumn{3}{|l|}{ Calculated composition } \\
\hline Crude protein (\%) & 20.00 & 22.00 \\
\hline Metabolizable energy (kcal/kg) & 3,450 & 3,400 \\
\hline $\mathrm{Ca}(\%)$ & 0.83 & 0.80 \\
\hline Available P (\%) & 0.49 & 0.42 \\
\hline Digestible lysine (\%) & 1.30 & 1.15 \\
\hline Digestible methionine + cistine $(\%)$ & 0.75 & 0.64 \\
\hline Digestible threonine (\%) & 0.83 & 0.72 \\
\hline Digestible tryptophan (\%) & 0.22 & 0.23 \\
\hline Choline (g/kg) & 1.20 & 1.00 \\
\hline $\mathrm{Na}(\%)$ & 0.19 & 0.18 \\
\hline
\end{tabular}

${ }^{1}$ Content/kg of the pre-initial diet - vit. A - 12,000 UI; vit. $\mathrm{D}_{3}-3,000 \mathrm{UI}$; vit $\mathrm{E}$ - 30 UI; vit. $K_{3} 3 \mathrm{mg}$; vit. $\mathrm{B}_{1} 2.7 \mathrm{mg}$; vit. $\mathrm{B}_{2}-8 \mathrm{mg}$; vit. $\mathrm{B}_{6} 4 \mathrm{mg}$; vit. $\mathrm{B}_{12} 40 \mathrm{mg}$; biotin - $0.16 \mathrm{mg}$; folic acid - $1.2 \mathrm{mg}$; pantothenic acid- $18.7 \mathrm{mg}$; nicotinic acid40 mg. Initial diet - vit. A - 9,000 UI; vit. $D_{3}-2,250 \mathrm{UI}$; vit E - $22.5 \mathrm{UI}$; vit. $\mathrm{K}_{3}$ $2.25 \mathrm{mg}$; vit. $\mathrm{B}_{1}-2 \mathrm{mg}$; vit. $\mathrm{B}_{2}-6 \mathrm{mg}$; vit. $\mathrm{B}_{6}-3 \mathrm{mg}$; vit. $\mathrm{B}_{12}-30 \mathrm{mg}$; biotin $0.12 \mathrm{mg}$; folic acid - $0.9 \mathrm{mg}$; pantothenic acid - $14 \mathrm{mg}$; nicotinic acid - $30 \mathrm{mg}$ ${ }^{2}$ Content/kg of the pre-inicial diet: Se - $0.6 \mathrm{mg}$; I - $2.25 \mathrm{mg}$; Co - $1.5 \mathrm{mg}$; Cu - $15 \mathrm{mg}$; Zn - 150 mg; Fe -150 mg; Mn - 60 mg. Initial diet: Se - 0.4 mg ; I - 1.50 mg; Co 1.0 mg; Cu - 10 mg; Zn -100 mg; Fe -100 mg; Mn - 40 mg 
0 - normal feces, 1 - pasty feces; 2 - liquid / pasty feces and 3- liquid feces.

For the evaluation of blood parameters, blood samples were collected through venous puncture from 48 females (12 per diet) on day 28 of the experiment, in tubes containing $2 \mathrm{~mL}$ of the anticoagulant EDTA. The evaluated blood parameters were: erythrocytes, hemoglobin, hematocrits, average globular volume, melanin concentrating hormone, average globular hemoglobin concentration, platelets, total leucocytes, neutrofils, eosinophils, monocytes, lymphocytes and basophils, as well as the ratio neutrofils/ lymphocytes.

The results of the performance and the blood parameters were submitted to analyses of variance considering the effect of diet, sex and block inside sex for the performance data, and the effect of diet and block for the blood parameters. When a significant difference $(\mathrm{P}<0.05)$ was shown in the $\mathrm{F}$ test, the diet means were compared using the Tukey's test. For the diarrhea data, the number of days that the piglets had diarrhea were analyzed using logistic regression, considering the same effects used in the variance analyzes. The statistical analyzes were done using the software SAS (2001).

\section{Results and Discussion}

Oregano essential oil produced bacteriostatic action on all the microorganisms tested and bactericide action against four bacteria. For the Salmonella typhimurium and Clostridium perfringens, the minimal lethal concentration was the same as the minimal inhibitory concentration (Table 2). Salmonella typhimurium causes typhoid fever and can infect human beings. It can be transmitted through water and food contaminated by fecal material (Jay, 1994). This same activity has already been observed in other studies in relation to the Salmonella enterica (Santurio et al., 2007) and Salmonella sp (Busatta, 2007).

Table 2 - In vitro antimicrobial activities of oregano essential oil on some microorganisms

\begin{tabular}{lcc}
\hline Microorganism & $\begin{array}{c}\text { Minimum } \\
\text { inhibitory } \\
\text { concentration }\end{array}$ & $\begin{array}{c}\text { Minimum } \\
\text { lethal } \\
\text { concentration }\end{array}$ \\
\hline Escherichia coli & $0.5 \mathrm{mg} / \mathrm{mL}$ & -1 \\
Salmonella typhimurium & $0.5 \mathrm{mg} / \mathrm{mL}$ & $0.5 \mathrm{mg} / \mathrm{mL}$ \\
Shigella dysenteriae & $0.5 \mathrm{mg} / \mathrm{mL}$ & $1.0 \mathrm{mg} / \mathrm{mL}$ \\
Clostridium perfringens & $0.5 \mathrm{mg} / \mathrm{mL}$ & $0.5 \mathrm{mg} / \mathrm{mL}$ \\
Staphylococcus aureus & $0.5 \mathrm{mg} / \mathrm{mL}$ & $2.5 \mathrm{mg} / \mathrm{mL}$ \\
Bacilus cereus & $0.5 \mathrm{mg} / \mathrm{mL}$ & -1 \\
\hline
\end{tabular}

${ }^{1}$ Not determined.
The antioxidant activity observed for the oregano essential oil was $98.88 \%$ by the methodology of the $\beta$-carotene/ Linoleic acid system. According to classification of Hassimotto et al. (2005), numbers for oxidation inhibition higher than $70 \%$ indicate good antioxidant action. By comparison, the hydroxi-butyl-toluene, considered a strong synthetic antioxidant, presents only $88.65 \%$ of protection against oxidation. The results of antioxidant activity for the $\mathrm{DPPH}$ method were expressed in $\mathrm{CE}_{50}$, which describes the concentration of oil capable of decreasing the initial concentration of the radical DPPH in $50 \%$. The $\mathrm{CE}_{50}$ obtained for the oregano essential oil was $174.17 \mathrm{mg} / \mathrm{mL}$. For the hydroxyl- butyl- toluene, the result was $80 \mathrm{mg} / \mathrm{mL}$. By comparing the two tested methodologies and literature data (Almeida-Doria et al., 2000; Capecka et al., 2005), it can be said that oregano essential oil is a powerful antioxidant, mainly in relation to inhibiting the oxidation of fatty acids.

The body weight on day 14 of trial was higher $(\mathrm{P}<0.05)$ in animals fed the positive control and oregano essential oil + zinc oxide diets, compared to those fed the negative control and oregano essential oil diets, which differed (Table 3). The same happened with the live weight at the end of the experiment. Similar results were obtained by Oetting et al. (2006) whose work showed significant higher weight gain and feed consumption with the use of conventional antimicrobials in relation to vegetable extracts.

Feed conversion ratio of the piglets receiving the positive control diet was better $\mathrm{P}<0.05$ ) than of those that received the negative control diet during the 1-35 day period. The diets consisting of oregano essential oil + zinc oxide and oregano essential oil showed intermediate results and did not differ from the other two treatments. According to Hernann et al. (2003), the use of vegetable extracts compared to conventional antimicrobials in nursery phase did not result in significant differences on feed conversion ratio.

The daily feed intake during the 0-14 day period was higher $(\mathrm{P}<0.05)$ in animals fed a positive control diet, compared to negative control and essential oil of oregano, but it did not differ from the essential oil of oregano + zinc oxide. In the 15-35 day period and the total period (1-35 days), the response in feed intake was similar to that observed in the 0-14 day period.

The average weight gain was higher $(\mathrm{P}<0.05)$ in the three periods in those animals fed a positive control and oregano essential oil + zinc oxide diets, compared to the negative control and oregano essential oil diets. There was no difference on growth performance (weight gain and feed intake) between the negative control and oregano essential 
Table 3 - Growth performance of weanling piglets fed diets with essential oil of oregano

\begin{tabular}{lcccc}
\hline Variables & \multicolumn{3}{c}{ Diets } \\
\cline { 2 - 4 } & $\begin{array}{c}\text { Negative } \\
\text { control }\end{array}$ & $\begin{array}{c}\text { Positive } \\
\text { Control }\end{array}$ & $\begin{array}{c}\text { Oregano } \\
\text { essential oil }\end{array}$ & $\begin{array}{c}\text { Oregano essential } \\
\text { oil + }\end{array}$ \\
zinc oxide
\end{tabular}

Averages followed by distinct letters in rows differ $(\mathrm{P}<0.05)$ significantly by Tukey test.

SEM = standard error of mean.

oil diets. This confirms the results by Hernann et al. (2003), Utiyama et al. (2006) and Costa et al. (2007), who did not find any significant differences in the performance of piglets that received vegetable extracts in different proportions and levels, compared to a diet free from any growth promoter. The positive control showed superior results for body weight, daily feed intake and daily weight gain in the 14 to 35 - day period. These results are consistent with those obtained by Oetting et al. (2006), where the antimicrobials improved live weight, daily feed intake and daily weight gain in all the nursery phases, and they also promoted higher villous patterns in the ileum of weaned piglets, compared to vegetable extracts of cloves, thyme and oregano. According to Tavares (1990), antimicrobials promote changes in the microbial population in the intestine through their bactericidal and bacteriostatic action against pathogenic bacteria, thus supporting the growth of beneficial bacteria.

In general terms, according to Hauptli et al. (2007), the results of experimental studies comparing the addition of synthetic antimicrobials and herbal extracts in pigs diets vary. Thus, it was not possible to clarify the mode of action of plant extracts in different animal species. Further studies are needed to prove its effectiveness and to determine the best ratio among different types of plant extracts and their concentrations in the diet and the optimal level of inclusion to maximize the performance of the animals and make them a viable alternative to the use of antibiotics as growth promoters (Oetting et al., 2006).

The number of pigs with diarrhea (scores 2 and 3) was low among animals fed positive control and essential oil of oregano + zinc oxide diets, and the number of piglets without diarrhea (scores 0 and 1 ) was high $(\mathrm{P}<0.05)$.
Among the piglets with diarrhea, the average duration, in days, was longer $(\mathrm{P}<0.05)$ in the piglets fed oregano essential oil and negative control diets. Most animals that had diarrhea for five and six days in the evaluated 14-day period (Table 4) had been on these diets. These results suggest that the oregano essential oil, at the studied dose, did not have the expected effect as antimicrobial neither improved the digestibility and absorption of food.

The value of hematocrit was influenced $(\mathrm{P}<0.05)$ by diets. The diet with the essential oil of oregano + zinc oxide was higher than negative control but it was not different from the others (Table 5). Hahn \& Baker (1993) concluded that the pharmacological dose of zinc (2,500-3,000 ppm) does not lead to toxicity and does not alter the hemoglobin and hematocrit. Therefore, this effect could be attributed to the essential oil of oregano individually, or to the essential oil of oregano + zinc oxide combination.

The average globular hemoglobin concentration in pigs receiving the essential oil of oregano was higher $(\mathrm{P}<0.05)$ than those who received the diet with essential oil of oregano + zinc oxide, without differing from the others.

Table 4 - Duration of diarrhea (days) in piglets during the first 14 days after weaning, fed diets containing antimicrobials

\begin{tabular}{lcccccccc}
\hline Diet & \multicolumn{7}{c}{ Days with diarrhea } \\
\cline { 2 - 7 } & 0 & 1 & 2 & 3 & 4 & 5 & 6 & Total \\
\hline Negative control b & 1 & 2 & 1 & 5 & 4 & 8 & 8 & 29 \\
Positive control a & 14 & 9 & 4 & 2 & 0 & 1 & 0 & 30 \\
Oregano essential oil b & 2 & 3 & 6 & 2 & 4 & 7 & 6 & 30 \\
Oregano essential oil + & & & & & & & & \\
zinc oxide a & 11 & 11 & 2 & 4 & 2 & 0 & 0 & 30 \\
Total & 28 & 25 & 13 & 13 & 10 & 16 & 14 & 119 \\
\hline
\end{tabular}

Diets followed by distinct letters differ $(\mathrm{p}<0.05)$ significantly by the $X^{2}$ test. 
Table 5 - Blood parameters in piglets at 55 days of age fed diets containing antimicrobials

\begin{tabular}{|c|c|c|c|c|}
\hline \multirow[t]{2}{*}{ Variables } & \multicolumn{4}{|c|}{ Diet } \\
\hline & $\begin{array}{l}\text { Nagative } \\
\text { control }\end{array}$ & $\begin{array}{l}\text { Positive } \\
\text { control }\end{array}$ & $\begin{array}{c}\text { Oregano } \\
\text { essential oil }\end{array}$ & $\begin{array}{c}\text { Oregano essential oil } \\
+ \text { zinc oxide }\end{array}$ \\
\hline Erythrocytes (x $10^{6} \mathrm{~mm}^{3}$ ) & $6.58 \pm 0.25$ & $6.65 \pm 0.20$ & $6.75 \pm 0.20$ & $6.98 \pm 0.20$ \\
\hline Hemoglobin (g/dL) & $11.43 \pm 0.48$ & $12.36 \pm 0.37$ & $11.80 \pm 0.37$ & $12.20 \pm 0.37$ \\
\hline Hematocrit (\%) & $36.41 b \pm 1.46$ & $39.20 \mathrm{ab} \pm 1.14$ & $36.90 \mathrm{ab} \pm 1.14$ & $40.99 a \pm 1.14$ \\
\hline Platelet $\left(\mathrm{mm}^{3}\right)$ & $532 \pm 48$ & $405 \pm 38$ & $473 \pm 38$ & $480 \pm 38$ \\
\hline Average globular volume $(\mathrm{fL})^{1}$ & $55.95 \pm 1.62$ & $59.15 \pm 1.27$ & $55.05 \pm 1.27$ & $58.73 \pm 1.27$ \\
\hline Melanin concentration volume $(\mathrm{pg})^{2}$ & $17.48 \pm 0.50$ & $18.64 \pm 0.39$ & $17.57 \pm 0.39$ & $17.65 \pm 0.39$ \\
\hline Average globular hemoglobin concentration (g/dL) & $31.33 a b \pm 0.73$ & $31.47 \mathrm{ab} \pm 0.57$ & $32.37 a \pm 0.57$ & $29.84 b \pm 0.57$ \\
\hline Total leucocytes $\left(\times 10^{6} \mathrm{~mm}^{3}\right)$ & $18.20 \pm 1.70$ & $17.70 \pm 1.33$ & $17.78 \pm 1.33$ & $17.49 \pm 1.33$ \\
\hline Neutrofils (\%) & $44.02 \pm 2.62$ & $39.87 \pm 2.05$ & $42.87 \pm 2.05$ & $39.87 \pm 2.05$ \\
\hline Eosinophils (\%) & $1.69 \pm 0.81$ & $1.68 \pm 0.64$ & $1.90 \pm 0.64$ & $2.35 \pm 0.64$ \\
\hline Monocytes (\%) & $1.65 \pm 0.38$ & $1.36 \pm 0.30$ & $1.70 \pm 0.30$ & $2.36 \pm 0.30$ \\
\hline Lymphocytes (\%) & $52.68 \pm 2.48$ & $57.04 \pm 1.94$ & $53.48 \pm 1.94$ & $54.70 \pm 1.94$ \\
\hline Neutrofils/limphocytes ratio & $0.85 \pm 0.09$ & $0.73 \pm 0.07$ & $0.81 \pm 0.07$ & $0.74 \pm 0.07$ \\
\hline
\end{tabular}

Means followed by distinct letters differ $(\mathrm{p}<0.05)$ significantly by Tukey test.

$1 \mathrm{fL}=$ fentoliters, fento $=$ one quadrillionth $\left(10^{-15}\right)$.

${ }^{2} \mathrm{pg}=$ picogram, pico $=$ one trillionth $\left(10^{-12}\right)$.

According to Dukes \& Reece (2006), values from 30 to $34 \mathrm{~g} / \mathrm{dL}$ for pigs are normal. The animals that received the essential oil of oregano + zinc oxide showed values slightly below the normal, attributed to zinc oxide or to the combination of the essential oil of oregano + zinc oxide. The average globular hemoglobin concentration provides the average percentage of cell volume occupied by hemoglobin and it represents an aid for the diagnosis of anemias when it is below normal concentration. In contrast, high concentrations reduce the solubility of hemoglobin, which may lead to crystallization. For all other analyzed blood variables, there were no statistical differences among treatments.

\section{Conclusions}

The antioxidant and antimicrobial activities evaluated in vitro show that essential oil of oregano is a potent antioxidant, especially in inhibiting the oxidation of fatty acids and with strong antimicrobial activity. However, the essential oil of oregano at the studied dose does not improve growth performance neither prevent diarrhea in weaned pigs.

\section{References}

ADER, P.; WESSAMANN, A.; WOLFFRAN, S. Bioavailability and metabolism of the flavonol quercetin in the pig. Free Radical Biology \& Medicine, v.28, p.1056-1067, 2000.

ALMEIDA-DORIA, R.F.; REGITANO-D'ARCE, A.B.M. Antioxidant activity of rosemary and oregano ethanol extracts in soybean oil under thermal oxidation. Ciência e Tecnologia de Alimentos, v.20, n.2, p.197-203, 2000.

ASSOCIATION OF OFFICIAL ANALYTICAL CHEMISTS - AOAC. Official methods of analysis. 16.ed. Arlington: AOAC International, 1995. 1025p.

BRAND-WILLIAMS, W.; CUVELIER, M.E.; BERSET, C. Use of free radical method to evaluate antioxidant activity. Lebensmittel-Wissenschaft und-Technologie, v.28, p.25-30, 1995.

BUSATTA, C.; MOSSI, A.J.; RODRIGUES, M.R.A. et al. Evaluation of origanum vulgare essential oil as antimicrobial agent in sausage. Brazilian Journal of Microbiology, v.38, p.610-616, 2007.

CAPECKAA, E.; MARECZEK, A.L.M. Antioxidant activity of fresh and dry herbs of some Lamiaceae species. Food Chemistry, v.93, p.223-226, 2005.

COSTA, L.B.; TSE, M.L.P.; MIYADA, V.S. Extratos vegetais como alternativas aos antimicrobianos promotores de crescimento para leitões recém-desmamados. Revista Brasileira de Zootecnia, v.36, n.3, p.589-595, 2007.

CROMWELL, G.L. Antimicrobial agents. In: MILLER, E.R.; ULLREY, D.E.; LEWIS, A.J. (Eds.). Swine nutrition. Stoneham: Butterworth - Heinemann, 1991. p.297-315.

DUKES, H.H.; REECE, W.O. Dukes, fisiologia dos animais domésticos. 12.ed. Rio de Janeiro: Guanabara Koogan, 2006. 926p.

HAHN, J.D.; BAKER, D.H. Growth and plasma zinc responses of young pigs fed pharmacologic levels of zinc. Journal of Animal Science, v.71, p.3020-3024, 1993.

HASSIMOTTO, N.M.A.; GENOVESE, I.S.; LAJOLO, F.M. Antioxidant activity of dietary fruits, vegetables, and commercial frozen fruit pulps. Journal of Agricultural and Food Chemistry, v.53, n.8, p.2928-35, 2005.

HAUPTLI, L.; LOVATTO, P.A.; HAUSCHILD, L. Comparação da adição de extratos vegetais e antimicrobianos sintéticos para leitões na creche através de meta-análise. Ciência Rural, v.37, n.4, p.1084-1090, 2007.

HERNANN, J.R.; HONEYMAN, M.S.; ZIMMERMAN, J.J. et al. Effect of dietary Echinacea purpurea on viremia and performance in porcine reprodutive and respiratory syndrome virus-infected nursery pigs. Journal of Animal Science, v.81, p.2139-2144, 2003.

HERNÁNDEZ, F.; MADRID, J.; GARCIA, V. et al. Influence of two plant extracts on broilers performance, digestibility, and digestive organ size. Poutry Science, v.83, p.169-74, 2004.

JAY, J.M. Microbiología moderna de los alimentos. 3.ed. Zaragoza: Acribia, 1994. 804p.

KALEMBA, D.; KUNICKA, A. Antibacterial and antifungal properties of essential oils. Current Medicinal Chemistry, v.10, p.813-829, 2003.

KAMEL, C.A novel look at a classic approach of plant extracts. Feed Mix, v.9, n.6, p.19-24, 2000. 
KOHLERT, C.; VAN RENSEN, I.; MARZ, R. et al. Bioavailability and pharmokinetics of natural volatile terpenes in animal and humans. Planta Médica, v.66, p.495-505, 2000.

LAMBERT, R.J.W.; SKANDAMIS, P.N.; COOTE, P.J. et al. A study of the minimum inhibitory concentration and mode of action of oregano essential oil, thymol and carvacrol. Journal of Aplied Microbiology, v.91, p.453-462, 2001.

MARCO, G.J. A rapid method for evaluation of antioxidants. Journal of the American Oil Chemists' Society, v.45, p.594-598, 1968.

MELLOR, S. Herbs and spices promote health and growth. Pig Progress, v.16, n.4, p.18-21, 2000.

MENSOR, L.L.; MENEZES, F.S.; LEITÃO, G.G. et al. Screening of Brazilian plant extracts for antioxidant activity by the use of DPPH free radical method. Phytoterapy Research, v.15, p.127-130, 2001.

NATIONAL RESEARCH COUNCIL - NRC. Nutrient requirements of swine, 10.ed. Washington, D.C.: National Academy Press, 1998. 211p.

OETTING, L.L.; UTIYAMA, C.E.; GIANI, P.A. et al. Efeitos de extratos vegetais e antimicrobianos sobre a digestibilidade aparente, o desempenho, a morfologia dos órgãos e a histologia intestinal de leitões recém-desmamados. Revista Brasileira de Zootecnia, v.35, n.4, p.1389-1397, 2006.

ROSTAGNO, H.S.; ALBINO, L.F.T.; DONZELE J.L. et al. Composição de alimentos e exigências nutricionais de aves e suínos. Tabelas brasileiras. 2.ed. Viçosa, MG: Editora UFV, 2005. 186p.

SANTURIO, J.M.; SANTURIO, D.F.; POZZATI, P. et al. Atividade antimicrobiana dos óleos essenciais de orégano, tomilho e canela frente a sorovares de Salmonella enterica de origem avícola. Ciência Rural, v.37, p.803-808, 2007.

SMINK, W. Oregano oil boost. Pig Progress, v.19, n.3, p.24-26, 2003.

STATISTICAL ANALYSIS SYSTEM - SAS. SAS user's guide: statistics. Version 8. Carry, 2001. 155p.

TAVARES, W. Manual de antibióticos e quimioterápicos antiinfecciosos. Rio de Janeiro: Atheneu, 1990. 515p.

UTIYAMA, C.E.; OETTING, L.L.; GIANI, P.A. et al. Efeitos de antimicrobianos, prebióticos, probióticos e extratos vegetais sobre a microbiota intestinal, a freqüência de diarréia e o desempenho de leitões recém-desmamados. Revista Brasileira de Zootecnia, v.35, n.6, p.2359-2367, 2006. 